\title{
Reformatorskie koncepcje działań oświatowych i opiekuńczo- -wychowawczych wobec dzieci zaniedbanych w Królestwie Polskim na przelomie XIX i XX wieku na tle rozwiązań europejskich
}

\begin{abstract}
Reformative Concepts of Education and Protective Activities Toward Neglected Children in the Kingdom of Poland at the Turn of the XIX-th Century in Comparison with European Solutions

After the January Uprising in the Kingdom of Poland, across half of the following century, industrial development was mostly connected with social reforms. One tragic consequence of it was the increase in the number of children without parental protection, juvenile beggars, tramps, young criminals and prostitutes. During the last thirty years of the 19th century it became a priority in the Kingdom of Poland to pay attention to the education and protection of children and teenagers from the poorest families. Numerous innovative and educational concepts were formulated at that time; some of them were used in centres for socially maladjusted young people, for instance in Studzieniec, Mariańska Wilderness or Struga, in centres for young prostitutes. The activity of educational centres and societies which organised the protection of children (for example, The National Society for the Prevention of Cruelty to Children) was given as an example.
\end{abstract}

Keywords: socially maladjusted young people, educational reforms, Kingdom of Poland

Intensyfikacja procesów urbanizacji i industrializacji nasiliła w XIX w. problem dzieci zaniedbanych i opuszczonych w całej Europie. Podobnie było w postyczniowym półwieczu w Królestwie Polskim, gdzie intensywne przemiany społeczne, demograficzne i kulturowe wpływały na zwiększenie liczby dzieci pozbawionych właściwej opieki rodzicielskiej, małoletnich żebraków, włóczęgów, młodocianych przestępców i prostytutek. Objęcie działaniami oświatowymi i wychowawczymi dzieci i młodzieży z rodzin zaniedbanych i najuboższych zostało uznane w Królestwie za społeczny priorytet ${ }^{1}$. Szukając

\footnotetext{
1 A. Bołdyrew, Społeczne inicjatywy na rzecz walki z patologiami w Królestwie Polskim na przełomie XIX i XX w., „Studia Gdańskie” t. XXXI, 2012, s. 254-256.
} 
sposobów ograniczenia skali niepokojącego zjawiska, polscy działacze społeczni obserwowali działania podejmowane na Zachodzie Europy i w Stanach Zjednoczonych, gdzie na przestrzeni XIX w. powstało wiele wspieranych przez państwo organizacji społecznych, zajmujących się losem zaniedbanych, pozbawionych opieki rodziców, nieprzystosowanych społecznie dzieci. Organizacje te zakładały placówki opiekuńczo-wychowawcze, tworzyły własne programy pracy pedagogicznej, prowadziły badania nad uwarunkowaniami destabilizacji życia rodzinnego.

Rozwiązania stosowane w Europie Zachodniej, poznawane przez polskich działaczy społecznych i oświatowych w czasie studiów i wyjazdów zagranicznych były źródłem inspiracji dla rodzimych inicjatyw. W 2 poł. XIX i na pocz. XX w. zagraniczne rozwiązania omawiano szeroko w periodykach pedagogicznych, czasopismach dla kobiet, prasie społeczno-kulturalnej, czasopiśmiennictwie lekarskim, prawniczym, ekonomicznym. Pisano o działaniach opiekuńczo-wychowawczych wobec dzieci opuszczonych, zwracano uwagę na problem przemocy w środowisku rodzinnym i deprawujący wpływ rodziny dopuszczającej się zaniedbań i manipulacji, zmuszającej nieletniego do kradzieży czy żebractwa. Analizowano przepisy prawne, mające zapobiegać zaniedbywaniu i przemocy, jak przyjęta w 1894 r. przez parlament angielski ustawa o ochronie dzieci przed okrucieństwem rodziców i opiekunów. Opisywano stosowane w krajach europejskich zasady ograniczania i pozbawiania władzy rodzicielskiej oraz formy opieki zastępczej nad dziećmi. Wiele uwagi poświęcano rozwiązaniom przyjętym we Francji w okresie III Republiki². Dążąc do założenia w Królestwie towarzystw prowadzących działalność opiekuńczo-wychowawczą na rzecz dzieci, interesowano się zagranicznymi stowarzyszeniami tego rodzaju. Pisano o licznych organizacjach opieki nad dziećmi we Francji³ Towarzystwach Opieki nad Dziećmi, założonymi w 1878 r. w Madrycie (Sociedad Protectora de los Niňos) i w 1880 r. w Mediolanie (La Sociétà Italiana Per la Protezione Dei Fanciulli), Towarzystwie Opieki nad Błąkającymi się po Ulicach Dziećmi w Nowym Yorku, a przede wszystkim o towarzystwach zapobiegania przemocy wobec dzieci utworzonym w 1874 r. New York Society for the Prevention of Cruelty to Children oraz założonym w 1884 w Londynie The National Society for the Prevention of Cruelty to Children ${ }^{4}$.

2 L. L., Pozbawienie rodziców władzy rodzicielskiej, „Gazeta Sądowa Warszawska” 1890, nr 15, s. 237-238; A. M., Ograniczenie władzy rodzicielskiej. Skutki wyroków karnych zagranicznych, „Gazeta Sądowa Warszawska" 1896, nr 13, s. 205-206.

3 We Francji na przestrzeni XIX w. powstało wiele organizacji opiekującymi się dziećmi, a także samotnymi matkami. Były to m.in. Société Protectrice de l'Enfance, Société Nationale des Amis de l'Enfance pour la Propagation de l'Allaitement Maternelle, Société Générale de Protection pour l'Enfance Abbandonnée ou Coupable.

4 Z. Pietkiewicz, Opieka społeczna. Dzieci, „Prawda” 1900, nr 47, s. 559; A. Moldenhawer, Stowarzyszenia i instytucye zagraniczne opiekujące się dziećmi, w: Niedole dziecięce, Warszawa 1882, s. 82-84; C. Heywood, Childhood and Children, w: Europe 1789 to 1914: Encyclopedia of the Age of Industry and Empire, red. J. Merriman, J. Winter, t. 1, Thomson Gale, Detroit 2006, s. 427-432. Pierwotnie nazwa istniejącej do dziś organizacji The National Society for the Prevention of Cruelty to Children brzmiała The London Society for the Prevention of Cruelty to Children. 
Zainteresowanie problemami dzieci zaniedbanych i opuszczonych było dystynktywną cechą twórczości pozytywistów, którzy stale pisali o sytuacji rodzinnej i społecznej „dzieci ulicy”. Określenie to spopularyzowane zostało w ostatnim 30-leciu XIX w. m.in. przez Elizę Orzeszkową, która w cyklu artykułów pt. O niedolach dziecięcych, zamieszczonych w 1876 r. w „Tygodniku Ilustrowanym” pisała o ubóstwie rodzin niebędących w stanie zapewnić elementarnych potrzeb potomstwa oraz o różnych formach zaniedbywania dzieci ${ }^{5}$. Na początku XX w. pojęcie „dzieci ulicy” powszechnie stosowano w publicystyce ${ }^{6}$. Termin „dzieci ulicy” stosowano zamiennie z określeniami „ulicznicy”, „dzieci moralnie zaniedbane”, „dzieci nędzy wielkomiejskiej”; często nazywano je na wzór francuskich publicystów „Arabami ulicy”. Pojęciami tymi na przełomie XIX i XX w. określano małoletnich włóczęgów, żebraków, osieroconych, bezdomnych kilkunastolatków żyjących bez opieki rodziny czy jakiejkolwiek instytucji społecznej, ale przede wszystkim dzieci z najuboższych rodzin, głównie w środowiskach wielkomiejskich, które formalnie wychowując się w rodzinnym domu, większość czasu spędzały poza nim, na ulicach, podwórkach, placach, w gronie rówieśników mających decydujący wpływ na ich zachowania, system wartości, wiedzę o świecie ${ }^{7}$. Celem niniejszego artykułu jest zasygnalizowanie kilku problemów związanych z koncepcjami i działaniami społecznymi na rzecz opieki i edukacji dzieci z najuboższych i zaniedbanych środowisk w Królestwie Polskim.

O sytuacji dzieci pozbawionych właściwej opieki i edukacji pisano na łamach prasy specjalistycznej i społeczno-kulturalnej Królestwa w ostatnim czterdziestoleciu XIX w. i na początku następnego stulecia, starając się pogłębić wiedzę i wrażliwość społeczną na los dzieci i społeczne implikacje ich zaniedbania. W 1897 r. na łamach „Głosu” podawano, że według szacunków działaczy Warszawskiego Towarzystwa Dobroczynności w Warszawie żyło 25-30 tys. moralnie, umysłowo i obyczajowo zaniedbanych dzieci ${ }^{8}$. Pedagodzy, działacze społeczni i oświatowi za priorytetowe zadanie uważali zorganizowanie społecznych form opieki, wychowania i edukacji, które miały pełnić funkcje prewencyjne, chroniąc dzieci przed demoralizacją. Postulowano zakładanie placówek, które wspierałyby prawidłowy przebieg procesów socjalizacji, przygotowywały dzieci z zaniedbanych społecznie i wychowawczo środowisk do uczestnictwa w życiu społecznym ${ }^{9}$.

Wiele uwagi sytuacji zaniedbanych dzieci i młodzieży poświęcał Bolesław Prus ${ }^{10}$. W swych Kronikach pisał o „dzieciach ulicy”, które uczą się próżniactwa, rozpusty, kra-

${ }^{5}$ E. Orzeszkowa, O niedolach dziecięcych, „Tygodnik Ilustrowany” 1876, nr 15, s. 236.

${ }^{6}$ Taki tytuł nosiła wydana w 1901 r. powieść Janusza Korczaka. J. Korczak, Dzieci ulicy, Warszawa 1901.

7 A. Mogilnicki, Dziecko i przestęstwo, Warszawa 1916, s. 28.

${ }^{8}$ Z życia stowarzyszeń. Opieka nad dziećmi, „Głos” 1897, nr 3, s. 62.

9 Zob. np. W obronie dzieci, „Głos” 1904, nr 17, s. 262; A. Jastrzębiec, Przytułek wychowawczo-poprawczy dla dziewcząt, „Tygodnik Mód i Powieści” 1891, nr 13, s. 102; A. Moldenhawer, Domy moralnie zaniedbanych dzieci, „Zdrowie” 1896, nr 5-7, s. 290-312; W. Połkotycki, Domy sierot, „Zdrowie” 1896, nr 5-7, s. 259-265; Nieletni przestępcy, „Gazeta Sądowa Warszawska” 1877, nr 14, s. 111.

${ }^{10}$ Szerzej na ten temat zob. C. Gałek, Myśl pedagogiczna Bolesława Prusa na tle pozytywizmu polskiego, Zamość 2005, s. 203-251. 
dzieży ${ }^{11}$. Zwracał uwagę czytelników na sytuację dzieci, wychowujących się w dusznej, przesyconej alkoholem atmosferze, zmuszonych do przedwczesnego dojrzewania i szukania środków utrzymania. Pisał o związkach między ubóstwem i niską kulturą rodziców a przyszłością dzieci, którym nie zapewniono ani właściwej opieki rodzicielskiej, ani edukacji szkolnej. Ubolewał nad chłopcami, którzy zaczynaja od gry w guziki, przechodza do niewinnych kłamstw i żebraniny, później dokuczaja mniejszym dzieciom, ścigaja obłakanych, a $w$ rezultacie biora się do noża ${ }^{12}$. Apelując do poczucia humanitaryzmu i solidarności opinii publicznej, prosił o wspieranie stowarzyszeń, zajmujących się opieką i wychowaniem zaniedbanych i najuboższych dzieci. Podkreślał potrzebę opracowania narzędzi diagnozy społecznej i metod pracy socjalno-wychowawczej. Uważał, że społeczeństwo polskie powinno podjąć dyskusję o uwarunkowaniach demoralizacji i przestępczości dzieci. Opisywał badania nad sytuacją nieletnich podejmowane w Europie Zachodniej, gdzie dzięki zasadzie nieukrywania złego przed samymi soba, opinia publiczna już wie, że istnieja trzynastoletnie prostytutki, trzynastoletni złodzieje, pijacy, włóczęgi i szesnastoletni mordercy. My dopiero zaczynamy dowiadywać się o tym ${ }^{13}$.

Prus był wielkim zwolennikiem zapewniania dzieciom opieki i wychowania w przytułkach, ochronkach, salach zajęć, ogrodach miejskich. Idea zakładania takich placówek łączyła działaczy społecznych i oświatowych. Za sprawę podstawowej wagi uważano organizowanie ochronek dla kilkuletnich dzieci. Już w latach 50. i 60. XIX w. problem zapewnienia opieki malcom ,pozbawionym dozoru” na stałe wpisał się w obszar zainteresowania działaczy dobroczynnych. Powoli, ale systematycznie wzrastała liczba zakładanych ochronek, przede wszystkich w miastach i osadach przemysłowych. Ich celem przede wszystkim miało być zapewnienie opieki dzieciom zagrożonym złym wpływom ulicy $^{14}$. W podobnym tonie wypowiadano się o zadaniach ochronek na łamach prasy w ostatnich dekadach XIX w. Ochronki w miastach i na wsiach miały zapobiegać nieszczęśliwym wypadkom i demoralizacji ${ }^{15}$. Na przełomie XIX i XX w. pedagodzy i działacze oświatowi podkreślali konieczność unowocześnienia metod pracy i większą troskę o zapewnienie prawidłowego rozwoju dzieci i przygotowanie ich do życia społecznego. Funkcjonujące według filantropijnego modelu ochronki uznano za pedagogiczny anachronizm, podtrzymujący i utrwalający nierówności społecznie ${ }^{16}$. Istotną rolę w zakładaniu ochronek po 1905 r. odegrało Towarzystwo Opieki nad Dziećmi.

Formą działań opiekuńczo-wychowawczych na rzecz starszych dzieci, które nie mogły już uczęszczać do ochronek, były zajęcia w różnego rodzaju salach, zakładanych na

11 B. Prus, Kroniki, t. XIX, oprac. Z. Szweykowski, Warszawa 1969, s. 179.

12 B. Prus, Dzieci warszawskie, ,Tygodnik Ilustrowany” 1905, nr 14, s. 244.

13 B. Prus, Kroniki, t. XX, oprac. Z. Szweykowski, Warszawa 1970, s. 80.

${ }^{14}$ E. Jachowicz, Ochrony i zakłady sierot warszawskiego Towarzystwa dobroczynności, w: Niedole dziecięce, Warszawa 1882, s. 122; J. Fijałek, Instytucje pomocy materialno-zdrowotnej w Łodzi i okręgu łódzkim, Łódź 1962, s. 139-140.

15 B. Prus, Kroniki, t. III, oprac. Z. Szweykowski, Warszawa 1954, s. 303-304; idem, Kroniki, t. X, oprac. Z. Szweykowski, Warszawa 1960, s. 250; idem, Kroniki, t. XIV, oprac. Z. Szweykowski, Warszawa 1964, s. 80-81.

16 J. M. (J. Marchlewski), Korzystna filantropia, „Głos” 1901, nr 26, s. 391; G. [J. Korczak], Tandeta dobroczynna, „Głos” 1904, nr 11, s. 163; g. (J Korczak), Od szyi pół metra, „Głos” 1904, nr 20, s. 306. 
przełomie XIX i XX w. w całym Królestwie Polskim przez towarzystwa dobroczynne, zgromadzenia zakonne i gminy wyznaniowe. Do sal zajęciowych (sale dla dziewcząt zazwyczaj miały charakter szwalni) przyjmowano dzieci od 7. do 14. roku życia. Podopiecznym zapewniano kształcenie zawodowe. Chłopcy uczyli się rzemiosła, zazwyczaj stolarstwa, ślusarstwa, krawiectwa, koszykarstwa lub kaletnictwa, dziewczęta szycia i haftu. Jednocześnie prowadzono nauczanie elementarne, często wykorzystywano przy tym elementarz Konrada Prószyńskiego. Troszczono się o wychowanie społeczno-moralne i patriotyczne, mimo zakazów władz zaborczych w wielu salach prowadzono nauczanie w języku polskim ${ }^{17}$.

Przeznaczone dla dzieci i młodzieży z najuboższych i zaniedbanych środowisk sale zajęciowe odegrały niebagatelną rolę w zakresie opieki i edukacji na przełomie XIX i XX w. Były namiastką szkolnictwa zawodowego, co było tym bardziej wartościowe, że obejmowały dzieci i młodzież, dla której nie były dostępne inne formy edukacji. Sale zajęciowe rozwijały umiejętności dzieci, spełniały zadania wychowawcze i kształcące. Udział w zajęciach przyzwyczajał dziecko do organizacji pracy, rzetelności, porządku i czystości. Wychowankowie nabierali wiary we własne siły, zyskiwali poczucie sprawstwa, uczyli się współpracy w grupie. W niektórych miejscach próbowano wykorzystać elementy slöjdu, rozwijać w oparciu o tę koncepcję wrażliwość estetyczną dzieci, stymulować pożądane postawy społeczno-moralne ${ }^{18}$. Działacze oświatowi podkreślali trudności związane $\mathrm{z}$ wykorzystaniem slöjdu w pracy z dziećmi z najuboższych rodzin, ale jednocześnie potrzebę jego popularyzacji. M. Dunin-Sulgustowska zwracała uwagę na mało widoczny wpływ slöjdu na dzieci ubogie, które wykazywały nieakuratność w robocie i dlatego podkreślała, iż w tym kierunku rozwój slöjdu jest pożądany. W Szwecyi jest on sprzymierzeńcem $w$ walce z nędz $q^{19}$.

W prasie pisano o utylitarności sal zajęciowych, dążono do spopularyzowania idei tej formy opieki i kształcenia w szerokich kręgach społeczeństwa ${ }^{20}$. Większość podopiecznych sal zajęciowych i szwalni pochodziła z ubogich rodzin, zagrożonych patologią, toteż zapewnienie im zajęć miało wymiar praktyczny, nie tylko jeśli chodzi o rozwijanie umiejętności zawodowych, przydatnych w dorosłym życiu, lecz także w zakresie organizacji czasu, kształtowania zamiłowania do pracy i szacunku do niej ${ }^{21}$.

Znacznym społecznym poparciem cieszyła się idea wyjazdów kolonijnych dla najuboższych dzieci ze środowisk miejskich ${ }^{22}$. Przeniesiono ją na polski grunt z krajów

17 H. Markiewiczowa, Działalność opiekuńczo-wychowawcza Warszawskiego Towarzystwa Dobroczynności 1814-1914, Warszawa 2002, s. 192-204; C. Kępski, Towarzystwa dobroczynności w Królestwie Polskim (1815-1914), Lublin 1993, s. 165.

18 Por. W. Grot-Bęczkowska, Söjd, jako czynnik wychowawczy, „Bluszcz” 1902, nr 9, s. 97-98.

19 M. Dunin-Sulgustowska, O slöjdzie i jego stanowisku wobec wychowania i hygieny, „Zdrowie” 1905, nr 1 , s. 80 .

20 Silva Rerum, „Kronika Rodzinna” 1889, nr 2 s. 63.

21 „Tygodnik Mód i Powieści” 1887, nr 3, s. 22.

22 B. Prus, Kroniki, t. VII, oprac. Z. Szweykowski, Warszawa 1958, s. 189-190; idem, Kroniki, t. XIII, oprac. Z. Szweykowski, Warszawa 1963, s. 336-337; idem, Kroniki, t. XIV, s. 286; idem, Kroniki, t. XV, oprac. Z. Szweykowski, Warszawa 1965, s. 8. 
Europy Zachodniej. Pierwsze kolonie wakacyjne zorganizowano w Szwajcarii; w szybkim czasie pomysł organizacji letnich wyjazdów, hartujących dzieci pod względem fizycznym, ale także znakomicie wpływających na ich rozwój psychiczny i moralny został urzeczywistniony w większości państw europejskich, Stanach Zjednoczonych, Australii i Japonii. Polacy interesowali się tą formą opieki na ubogimi i zaniedbanymi dziećmi, wiele pisano o niej w prasie społecznej ${ }^{23}$. Pierwszy wyjazd zorganizowano w Warszawie w 1882 r., w kolejnych latach powtarzano akcje kolonijne w Warszawie, a na przełomie XIX i XX w. wyjazdy organizowano w większości miast gubernialnych ${ }^{24}$. Najważniejszym celem kolonii letnich było poprawienie zdrowotności i higieny dzieci z najuboższych rodzin, ale równie istotny był pedagogiczny wymiar wyjazdów. Dzieci pozostawały pod opieką wykwalifikowanych wychowawców, bawiły się na powietrzu i w wodzie, grały w gry zespołowe, wędrowały po okolicy. Poznawały piękno przyrody, zyskiwały możliwość wartościowego spędzania wolnego czasu. Wyjazdy zapewniały wychowankom zdobycie doświadczeń i umiejętności umożliwiających prawidłowy przebieg procesów socjalizacji. Uczestnictwo w koloniach pomagało rozwinąć kompetencje społeczne, umiejętności nawiązywania wartościowych kontaktów w grupie rówieśniczej. Dzięki temu letnie wyjazdy pełniły także funkcje prewencyjne, pomagając chronić dzieci przed deprawacją ${ }^{25}$.

Kolonie letnie nie były w stanie zapewnić opieki wszystkim chętnym. Zdecydowana większość niezamożnych dzieci nie mogła wziąć w nich udziału. Pedagodzy i lekarze pisali o fatalnych konsekwencjach nadmiernie gęstniejącej miejskiej zabudowy, a co za tym idzie braku miejsca do zabaw i odpoczynku. Zwracano uwagę na potrzebę zapewnienia dzieciom ruchu na powietrzu, swobodnej zabawy z rówieśnikami, aktywności wzmacniającej zdrowie fizyczne, mającej istotny wpływ na rozwój intelektualny, spo-

${ }^{23}$ Letnie kolonie dla dzieci, „Kłosy” 1882, nr 888, s. 12-13, nr 889, s. 29-30; W. Kozłowski, O rozpowszechnianiu kolonii letnich i ogrodów dziecięcych, „Zdrowie” 1905, nr 2, s. 172. Por. Wicherkiewicz, Poznańskie kolonie wakacyjne, „Zdrowie” 1886, nr 3, s. 2-3.

24 „Gazeta Radomska” 1890, nr 25, s. 2; „Tygodnik Ilustrowany” 1900, nr 49, s. 974; J. Supady, Powstanie i rozwój kolonii letnich dla dzieci w Lodzi na przełomie XIX i XX wieku, „Zdrowie Publiczne” 1977, nr 3, s. 193-198; M. Demel, Pedagogiczne aspekty warszawskiego ruchu higienicznego (1864-1914), Wrocław 1964, s. 137-139; M. Sobczyńska, Kolonie letnie w Ciechocinku dla chorych dzieci z guberni płockiej, „Notatki Płockie" 2007, nr 2, s. 6-10; C. Kępski, op. cit., s. 88-89.

25 Pedagodzy i lekarze zwracali uwagę na społeczno-moralne znaczenie udziału dzieci w koloniach letnich. Doktor M. Berenstein w 1899 r. na łamach „Czasopisma Lekarskiego” pisał: Co się tyczy moralnego $i$ wychowawczego wplywu, to pewnie wszyscy, którzy mieli możność bliższego poznania ich życia, uważaja go za bardzo ważne. [...] Z powodu przyjacielskich stosunków dosyć łatwo można poznać charakter dzieci $i$ dobroczynnie na nie wptywać. Takie głosy daja się często styszeć w Europie Zachodniej $i$ w krajach, gdzie od dawna wprowadzono przymus szkolny, gdzie prawie wszyscy umieja czytać, gdzie robotnicy i ubodzy rzemieślnicy pod względem wykształcenia i rozwoju umysłowego stoja bez porównania wyżej od naszego proletaryatu. Samo przez się rozumie, że wplyw wychowawczy kolonii w naszym mieście powinien być jeszcze wybitniejszy [...] Takie dzieci dopiero $w$ kolonii doświadczaja wpływu ludzi do pewnego stopnia majacych przygotowanie pedagogiczne; tam ucza się porządku, przyzwoitości, czystości i poznaja zasadnicze prawidła moralne [...] prawie wszystkie dzieci wracaja do domu zdolniejszemi fizycznie i z pewnym taktem nabywszy znakomity zapas nowych wiadomości o życiu wiejskiem, o pracy $w$ polu, umiłowawszy przyrodę $i$ wzbogaciwszy swój widnokrag umystowy. Można śmiało powiedzieć, że kolonie u nas dla wielu dzieci zastępuja szkotę. M. Berenstein, O kolonjach letnich dla ubogich dzieci w Lodzi, „Czasopismo Lekarskie” 1899, nr 9, s. 405. 
łeczny i moralny ${ }^{26}$. Konieczność troski o pozostawianie w zatłoczonych miastach ogólnie dostępnych miejsc do zabaw dla dzieci podkreślali wybitni pedagodzy i działacze społeczni - Jan Władysław Dawid, Aniela Szycówna, Iza Moszczeńska, Janusz Korczak, Zygmunt Kramsztyk ${ }^{27}$. Aniela Szycówna, zwracając uwagę na rolę ogrodów pisała, że są one szczególnie ważne w opiece nad dziećmi z zaniedbanych środowisk, bowiem rodzice ubodzy i nieoświeceni nie moga i nie umieja zajać się dziećmi, puszczaja je więc samopas, rzucając na pastwę złych wpływów ulicy, przez co do skarlenia fizycznego dołacza się wczesne zepsucie moralne ${ }^{28}$. Zakładając ogrody dla dzieci odwoływano się do rozwiązań organizacyjnych i pedagogicznych stosowanych na Zachodzie, ale za najlepiej funkcjonujące uznano ogrody założone w Krakowie przez dr. Henryka Jordana ${ }^{29}$. W Królestwie ogrody miejskie powstały w Warszawie, Lublinie, Kaliszu, Płocku, Włocławku, Częstochowie i Sosnowcu. Ich brak był szczególnie dotkliwy w Lodzi.

O położeniu pozbawionych właściwej opieki rodzicielskiej dzieci, które szukały oparcia w grupach rówieśniczych, kierowanych przez cieszących się charyzmą i doświadczeniem w działalności przestępczej nastolatków pisał w 1910 r. na łamach „Nowych Torów” A. Jaśkiewicz. Podkreślał, że zaniedbane dzieci bardzo często wchodziły na drogę przestępczą, stawały się członkami oddziałów wywiadowczych różnych włamywaczy lub pospolitych złodziei, kandydatami na ławe oskarżonych ${ }^{30}$. Zastanawiając się nad możliwościami przeciwdziałania deprawacji dzieci, opisywał działające w Stanach Zjednoczonych i Francji kluby dla „dzieci ulicy”, prowadzone przez nie same. Postulował zakładanie podobnych w Królestwie. Koncepcja ta jednak z powodu braku wsparcia filantropów nie została zrealizowana.

Szczególnie istotnym problemem była organizacja placówek dla dzieci i młodzieży, które weszły w konflikt z prawem. Inercja władz zaborczych w tej dziedzinie zmuszała działaczy społecznych i oświatowych do wzięcia odpowiedzialności za zbudowanie zakładów dla zaniedbanej wychowawczo młodzieży. Wynikało to z niezgody na osadzanie nieletnich w więzieniach i przekonania o potrzebie zapewnienia im opieki i edukacji. Zakłady poprawcze dla niedostosowanych społecznie dzieci i młodzieży organizowano we wszystkich krajach europejskich. Polscy społecznicy w czasie podróży zagranicznych obserwowali ich funkcjonowanie. Odwiedzano i opisywano w prasie specjalistycznej i społeczno-kulturalnej placówki cieszące się opinią najlepszych, w tym: kolonię w Met-

26 Ogrody dla dzieci, „Przegląd Pedagogiczny” 1893, nr 11, s. 145-146; „Biblioteka Warszawska” 1894, t. II, s. 195-196; A. Szycówna, Ogród zabaw, gier i zajęć praktycznych dla dzieci, „Zdrowie” 1912, nr 8, s. 624-626; W.R. Kozłowski, O rozpowszechnieniu kolonii letnich..., s. 171-179.

27 J.Wł.D. [J.W. Dawid], Publiczne place do zabaw dla dzieci, „Przegląd Pedagogiczny” 1890, nr 14, s. 157-158; I. Moszczeńska, Dzieci w Warszawie, „Przegląd Pedagogiczny” 1898, nr 20, s. 359; A. Szycówna, Ogrody dziecięce imienia Rau'a, „Zdrowie” 1904, nr 1, s. 3-11; J. Tchórznicki, Ogrody do zabaw i gier dla dzieci, „Przegląd Pedagogiczny” 1903, nr 22, s. 267; g. [J. Korczak], Skwery, „Głos” 1904, nr 23, s. 356; g. [J. Korczak], Ogrody i skwery, „Głos” 1904, nr 26, s. 402; Kronika miesięczna, „Biblioteka Warszawska” 1898, nr 4, s. 371-378; Z tygodnia na tydzień, „Tygodnik Ilustrowany” 1899, nr 27, s. 519.

28 A. Szycówna, Ogrody dziecięce imienia Rau'a, „Zdrowie” 1904, nr 1, s. 5.

29 W.R. Kozłowski, Postęy wychowania fizycznego w ostatniem dziesięcioleciu, „Zdrowie” 1908, nr $10-11$, s. 772 .

${ }^{30}$ A. Jaśkiewicz, $W$ walce o godność człowiecza..., „Nowe Tory” 1910, nr 1, s. 7. 
tray koło Tours, kolonię w majątku Rÿsselt koło Zutphen w Holandii, zakład poprawczy w Marienhof koło Drezna, dom dla młodocianych przestępców i dzieci pozbawionych opieki w Horn koło Hamburga, włoskie kolonie rolnicze (m.in. w Monkukko), zakłady w Belgii i Szwajcarii ${ }^{31}$. Korzystając z doświadczeń zakładów, które funkcjonowały na zasadzie osad rolnych i rzemieślniczych, przygotowano ustawę i powołano w $1871 \mathrm{r}$. w Królestwie Polskim Towarzystwo Osad Rolnych i Przytułków Rzemieślniczych. Jego celem była praca nad moralna poprawa dzieci płci obojga, które za występek przez sąd na karę skazane zostały, tudzież nad polepszeniem losu nieletnich żebraków $i$ włóczęgów bez przytułku ${ }^{32}$. Towarzystwo miało zakładać osady rolne i przytułki rzemieślnicze, zapewniające elementarne wykształcenie oraz praktyczne przygotowanie do pracy zawodowej.

W maju 1876 r. otwarto osadę dla chłopców w Studzieńcu. Przyjęto system rodzinnoklasowy, składający się z 5 klas. Każda miała swojego wychowawcę i zajmowała osobny domek w osadzie ${ }^{33}$. Grupy nazywane były rodzinami, a wychowawcy ojcami rodzin ${ }^{34}$. Przyjęty system wychowania zespołowego był metodą resocjalizacji i budowania więzi społecznych. Fundamentem oddziaływania penitencjarnego było wychowanie moralnoreligijne, troszczono się także o aktywność fizyczną podopiecznych. Wychowankowie zdobywali wykształcenie na poziomie elementarnym. Trudno było rozszerzyć zakres przekazywanej wiedzy teoretycznej, co wynikało z intelektualnych możliwości trafiających do zakładu chłopców. Większość z nich była analfabetami. Na wysokim poziomie stało natomiast nauczanie zawodowe. Każdy z wychowanków Studzieńca zapoznawał się z pracą rolnika, a następnie z jednym z rzemiosł podstawowych: stolarstwem, kołodziejstwem, kotlarstwem, ciesielstwem itd. Wychowankowie zyskiwali zatem umiejętności potrzebne do pracy w rolnictwie i rzemiośle ${ }^{35}$. Bardzo rozwinięty był system opieki nad chłopcami opuszczającymi zakład. Udzielano im wsparcia finansowego, umieszczano u godnych zaufania rzemieślników. W przypadku wychowanków pochodzących ze szczególnie zdemoralizowanych środowisk, szukano zastępczych opiekunów sprawujących pieczę nad opuszczającym zakład ${ }^{36}$. Do 1881 r. na 97

\footnotetext{
31 Osada rolniczo-karna w Mettray, „Biblioteka Warszawska” 1843, nr 4, s. 772-778; A. Moldenhawer, Krótka wiadomość o pierwszych osadach rolnych i o ich założycielach, „Kłosy” 1874, nr 479, s. 158-159, nr 480, s. 172-174; A. Moldenhawer, O zakładach karnych dla nieletnich przestępców i dzieci potrzebujących opieki, „Przegląd Sądowy” 1871, t. 10, s. 159-203; Z. Daszyńska-Golińska, Ochrona dzieci we Francji, „Prawda” 1908, nr 47, s. 573; nr 48, s. 586.

32 E.J. Dukaczewski, Szkoly $i$ zakłady specjalne dla dzieci trudnych $w$ XIX i na początku XX wieku, w: Dzieje szkolnictwa i pedagogiki specjalnej, red. S. Mauersberg, Warszawa 1990, s. 138.

33 Studzieniec, „Gazeta Sądowa Warszawska” 1882, nr 22, s. 175-178; D. Raś, Rodziny ubogie i przestępczość od XVI do XX wieku. Warunki życia, badania psychologiczno-spoleczne, dobroczynność $i$ wychowanie młodzieży, Kraków 2011, s. 70.

${ }^{34} \mathrm{O}$ organizacji i metodach pracy wychowawczej w Studzieńcu zob. A. Moldenhawer, Towarzystwo osad rolnych i przytułków rzemieślniczych oraz jego zakłady, w: Niedole dziecięce, Warszawa 1882, s. 211-235.

35 Nieletni przestępcy, „Gazeta Sądowa Warszawska” 1877, nr 14, s. 111.

${ }^{36}$ Cyt. za: H. Szymańska, Z problemów przestępczości nieletnich $w$ drugiej połowie XIX wieku, „Przegląd Penitencjarny" 1964, nr 2, s. 140.
} 
zwolnionych wychowanków 16 powierzono pieczy rodziców, a 68 opiekunom ${ }^{37}$. W ciągu pierwszych dwudziestu lat istnienia osada w Studzieńcu zastużyła się społeczeństwu, wychowujac 890 nieletnich $^{38}$. Wierzono, że będzie ona wzorem dla kolejnych zakładów dla dzieci i młodzieży zagrożonych demoralizacją, że placówki te rozwiążą szereg problemów społecznych - zapobiegną włóczęgostwu, żebractwu, przestępczości ${ }^{39}$. Do Studzieńca przyjeżdżali specjaliści w zakresie prawa, psychologii, pedagogiki z Królestwa i pozostałych ziem polskich oraz $\mathrm{z}$ innych państw europejskich ${ }^{40}$. W $1891 \mathrm{r}$. w miejscowości Puszcza Mariańska Towarzystwo otworzyło zakład dla dziewcząt.

Cennym przedsięwzięciem było założenie w 1911 r. w Strudze pod Warszawą przez Towarzystwo Opieki nad Więźniami „Patronat” zakładu dla chłopców, zapewniającego wychowanie społeczno-moralne i przygotowanie zawodowe. Placówka, zwana Szkołą Pracy, była przeznaczona dla 40 chłopców w wieku od 12. do 17. lat, wypuszczonych z więzień. Wychowankowie zdobywali praktyczne umiejętności w warsztatach szewskim, tkackim i stolarskim. Uczono ich pisania, czytania, matematyki i historii Polski ${ }^{41}$.

Działania opiekuńczo-wychowawcze podejmowano wobec dziewcząt zagrożonych prostytucją oraz wobec nieletnich prostytutek. Skala potrzeb w tym zakresie była bardzo duża; dość przypomnieć, że w miastach przemysłowych prostytucji oddawały się już 10-12-letnie dziewczynki ${ }^{42}$. Najbardziej znanym przytułkiem dla prostytutek był funkcjonujący w Warszawie przy ulicy Żytniej Zakład Opieki Najświętszej Panny Marii (tzw. magdalenki). Od 1862 r. prowadziło go Zgromadzenie Sióstr Matki Bożej Miłosierdzia, założone przez Ewę z Sułkowskich Potocką, która metody pracy resocjalizacyjnej poznała we francuskiej placówce dla prostytutek w Laval. To samo zgromadzenie założyło kilka kolejnych zakładów dla zagrożonych demoralizacją dziewcząt i prostytutek. Od 1881 r. w Derdach w powiecie Piaseczno funkcjonował przytułek nazywany domem św. Józefa lub Józefowem. W Płocku w 1899 r. siostry ze Zgromadzenia Matki Bożej Miłosierdzia połączyły się z miejscowym Zgromadzeniem „Bożej Miłości”, które prowadziło założony w 1889 r. z inspiracji Jakobiny Łabanowskiej i księdza Antoniego Nowowiejskiego przytułek, zwany Zakładem Anioła Stróża. W Częstochowie zgromadzenie założyło przytułek dla prostytutek w 1908 r. W przededniu odzyskania niepodległości na

37 Studzieniec, „Gazeta Sądowa Warszawska” 1882, nr 22, s. 176.

38 Silva Rerum, „Kronika Rodzinna” 1896, nr 6, s. 188.

39 B. Prus, Kroniki, t. I, cz. II, oprac. Z. Szweykowski, Warszawa 1956, s. 15-16; idem, Kroniki, t. II, oprac. Z. Szweykowski, Warszawa 1953, s. 204, s. 499; idem, Kroniki, t. IV, oprac. Z. Szweykowski, Warszawa 1955, s. 284-285; idem, Kroniki, t. VII..., s. 274; idem, Kroniki, t. XI, oprac. Z. Szweykowski, Warszawa 1961 , s. $180-181$.

40 Trzeci Zjazd przedstawicieli zakładów poprawczych w Moskwie, „Gazeta Sądowa Warszawska” 1890, nr 36, s. 573-574, nr 37, s. 589-590.

${ }^{41}$ Z. Zbyszewska, Ministerstwo polskiej biedy. Z dziejów Towarzystwa Opieki nad Więźniami „Patronat” $w$ Warszawie 1909-1944, Warszawa 1983, s. 32-33.

42 J.M. Kamiński, O prostytucji, Warszawa 1975, s. 135; B. Margulies, Prostytucya w Łodzi, „Zdrowie” 1906, nr 8, s. 539-547. 
obszarze Królestwa powstał jeszcze jeden zakład dla „magdalenek”, utworzony w Rado$\mathrm{miu}^{43}$

Przytułek dla moralnie upadłych dziewcząt, funkcjonujący od 1897 r. jako Dom Schronienia św. Małgorzaty założyła w 1895 r. Ludwika Moriconi44. W Ciechanowie opieką nad „dziewczętami upadłymi” zajmowało się Zgromadzenie Sióstr Służek NMP Niepokalanej (służki). Istniejący od 1883 do ok. 1890 r. przytułek dla dziewcząt „,moralnie zagrożonych" w Lublinie pomagało prowadzić Zgromadzenie Sióstr Franciszkanek od Cierpiących (franciszkanki). W 1895 r. w Lublinie Zakład św. Antoniego - kolejny przytułek dla dziewcząt i kobiet, które chciały porzucić prostytucję, założył ksiądz Ignacy Kłopotowski ${ }^{45}$. Trudno określić, jakie metody i formy pracy stosowano w prowadzonych przez zgromadzenia zakonne zakładach. Wiadomo, że metodą resocjalizacji była praca, modlitwa i udział w uroczystościach religijnych ${ }^{46}$. Podopieczne przytułków zajmowały się szyciem, haftem i praniem bielizny. Bliższych informacji nie podawano. Wywoływało to krytykę opinii publicznej, której nie podobała się izolacja zakładów, szczególnie widoczna w przypadku ,magdalenek"47.

Na przełomie XIX i XX w. powstało wiele organizacji założonych przez świeckich działaczy społecznych, które miały opiekować się dziewczętami i chronić je przed demoralizacją i prostytucją. W 1902 r. powołano Chrześcijańskie Towarzystwo Ochrony Kobiet $^{48}$. Jego oddziały terenowe funkcjonowały w Łodzi, Radomiu, Włocławku, Częstochowie, Lublinie, Piotrkowie, Płocku i Kielcach ${ }^{49}$. Towarzystwo skupiało osoby wyznania katolickiego i ewangelickiego. Prowadziło akcje edukacyjne, założyło kilka przytułków dla dziewcząt i kobiet. W 1904 r. utworzono Żydowskie Towarzystwo Ochrony Kobiet, zwane później Warszawskim Żydowskim Towarzystwem Ochrony Kobiet ${ }^{50}$. Założyło ono przytułek, prowadziło biuro pośrednictwa pracy, ognisko dla dziewcząt, tanią kuchnię, udzielało zapomóg i pożyczek. Odrębną organizacją, realizującą podobne cele, było Łódzkie Żydowskie Towarzystwo Ochrony Kobiet ${ }^{51}$. Na przełomie XIX i XX w. zakładano także stowarzyszenia, których celem było otoczenie opieką i zapewnienie edukacji

43 J. Bar, Rozwój stanów doskonałości w Polsce. Zgromadzenie Matki Bożej Miłosierdzia (1862-1962), „Prawo Kanoniczne” 1966, nr 3-4, s. 41-47, 64-88.

${ }^{4}$ Warszawski Dom Schronienia św. Małgorzaty, „Czystość” 1905, nr 6, s. 1.

${ }^{45}$ C. Kępski, op. cit., s. 90.

46 S. hr Al., Dla upadtych, „Kurier Warszawski” 1881, nr 251, s. 2.

47 J.M. Kamiński, op. cit., s. 210-212. Por. Poseł Prawdy [A. Świętochowski], Liberum veto, „Prawda” 1881, nr 47, s. 562.

${ }^{48}$ Nad otchłania, „Gazeta Sądowa Warszawska” 1902, nr 13, s. 196-198; „Biblioteka Warszawska” 1902, nr 2, s. 169 i n.; Towarzystwo Ochrony Kobiet, „Tygodnik Mód i Powieści” 1902, nr 51, s. 605-606; E. Mazur, Dobroczynność w Warszawie XIX wieku, Warszawa 1999, s. 30; Warszawskie chrześcijańskie Towarzystwo ochrony kobiet, „Czystość” 1909, nr 33-34, s. 524-525.

49 Kalendarz Informacyjno-Encyklopedyczny na rok 1914, s. 572-575; VIII Międzynarodowy Kongres Komitetów Walki z handlem kobietami i dziećmi, Warszawa 1930, s. 33-34.

${ }^{50}$ Kronika. Wiadomości społeczne „Prawda” 1904, nr 33, s. 395; VIII Międzynarodowy..., s. 55.

${ }_{51}$ M. Sikorska-Kowalska, E. Wiatr, Łódzkie Żydowskie Towarzystwo Ochrony Kobiet w Eodzi 1914-1939, „Studia z Historii Społeczno-Gospodarczej XIX i XX w.” 2008, nr 5, s. 328 i n. 
dziewczętom i młodym kobietom, by przygotować je do dorosłego życia i pomóc w znalezieniu godnej pracy. Taką działalnością zajmowało się Ewangelicko-Augsburskiego Stowarzyszenie Opieki nad Dziewicami, zarejestrowane w 1898 r. Lokalne oddziały działały w Łodzi, Pabianicach, Tomaszowie Mazowieckim i Zduńskiej Woli ${ }^{52}$. W Łodzi w 1903 r. przy kościele św. Jana założono Stowarzyszenie Dziewic Ewangelickich, troszczące się o wychowanie religijne i społeczno-moralne podopiecznych. W niedzielę i święta dziewczęta zbierały się w przyparafialnej świetlicy, gdzie wykonywały robótki ręczne, czytały Pismo Święte i książki religijne, gromadzone w prowadzonej przez Stowarzyszenie bibliotece. Organizacja pomagała dziewczętom w znalezieniu pracy i mieszkania. Zapewnieniem wsparcia moralnego swym podopiecznym zajmowało się utworzone w 1909 r. Towarzystwo Opieki nad Dziewicami w Ozorkowie ${ }^{53}$. Brak środków finansowych uniemożliwiał rozwinięcie działalności wielu organizacji. Ich założyciele pisali o wielu interesujących koncepcjach działań opiekuńczych, wychowawczych i oświatowych, które jednak w realiach Królestwa nie mogły być w pełni zrealizowane ${ }^{54}$.

Rodzi się pytanie, w jakim stopniu koncepcje teoretyczne i model działalności placówek opiekuńczo-wychowawczych w Królestwie Polskim były wytworem samodzielnej, oryginalnej polskiej myśli, a w jakim przeniesieniem na grunt Królestwa wzorców zachodnich? Czy istniejące warunki nie sprzyjały dependentyzmowi? ${ }^{55}$ Czy poznanie obcych idei i rozwiązań inspirowało do tworzenia własnych koncepcji? Trudno udzielić jednoznacznej odpowiedzi na postawione pytania, ale analiza działalności wielu stowarzyszeń i placówek wskazuje, że ich założyciele twórczo adaptowali zachodnioeuropejskie wzorce. Na bazie tych doświadczeń tworzono wiele oryginalnych koncepcji. Wielu polskich działaczy wypracowało własne, dostosowane do lokalnych potrzeb i możliwości metody pracy z dziećmi i młodzieżą, opierając się na teoretycznych refleksjach polskich pedagogów, w tym Jana Władysława Dawida i Stanisława Karpowicza. Inna rzecz, że konieczność dostosowania się do trudnych w politycznym i ekonomicznym wymiarze realiów Królestwa poniekąd a priori wykluczała groźbę dependentyzmu. Polscy społecznicy, funkcjonując w zupełnie odmiennych warunkach, musieli zmierzyć się z problemami, z jakimi nie musiały radzić sobie organizacje zachodnioeuropejskie, a ich działania wymagały głębszego zaangażowania. Będąca wynikiem celowego leseferyzmu w dziedzinie opieki, a po części także oświaty polityka władz zaborczych sprawiała, że kwestie opieki i wychowania najuboższych i zaniedbanych dzieci pozostawały niemal całkowicie w obszarze działań społecznych. Stałe trudności finansowe, lokalowe, utrudnienia ze

${ }^{52}$ Ewangelicko-augsburskie Stowarzyszenie opieki nad dziewicami w Warszawie, „Zwiastun Ewangeliczny" 1899 , nr 6, s. 175-176.

53 W. Jaworski, Przemiany legalnego życia społecznego w Królestwie Polskim w latach 1864-1914, Sosnowiec 2006, s. 259.

${ }^{54} \mathrm{O}$ potrzebach i obszarach działań pisano wielokrotnie na łamach postępowej prasy społecznej i w czasopismach kobiecych, m.in. w „Ogniwie”, „Sterze”, „Czystości”, „Głosie”, „Prawdzie”, „Bluszczu”.

${ }_{55}$ Dependentyzm przejawia się w apriorycznym założeniu, że wartości prezentowane przez środowisko obce, zewnętrzne mają większą wagę i znaczenie niż normy i wartości przyjęte we własnym środowisku, które jest deprecjonowane, uważane za peryferyjne i obskuranckie. Por. L. Krzywicki, Jeden z pogromców, w: idem, Dzieła, t. IX, red. H. Hołda-Róziewicz, Warszawa 1974, s. 51. 
strony carskich urzędników powodowały, że w wielu przypadkach konieczność troski o kwestie organizacyjne utrudniała realizację formułowanych koncepcji wychowawczych i oświatowych. Część z nich została wprowadzona w życie dopiero w odrodzonej Polsce.

\section{Bibliografia}

Al. hr S., Dla upadtych, „Kurier Warszawski” 1881, nr 251, s. 2.

Bar J., Rozwój stanów doskonałości w Polsce. Zgromadzenie Matki Bożej Miłosierdzia (1862-1962), „Prawo Kanoniczne” 1966, nr 3-4, s. 41-47, 64-88.

Berenstein M., O kolonjach letnich dla ubogich dzieci w Łodzi, „Czasopismo Lekarskie” 1899, nr 9, s. 405.

„Biblioteka Warszawska” 1894, t. II, s. 195-196.

„Biblioteka Warszawska” 1902, nr 2, s. 169 i n.

Bołdyrew A., Społeczne inicjatywy na rzecz walki z patologiami w Królestwie Polskim na przełomie XIX i XX w. „Studia Gdańskie” t. XXXI, 2012, s. 254-256.

D. J.Wł. [Dawid J.W.], Publiczne place do zabaw dla dzieci, „Przegląd Pedagogiczny” 1890, nr 14, s. $157-158$.

Daszyńska-Golińska Z., Ochrona dzieci we Francji, „Prawda” 1908, nr 47, s. 573; nr 48, s. 586.

Demel M., Pedagogiczne aspekty warszawskiego ruchu higienicznego (1864-1914), Wrocław 1964.

Dukaczewski E.J., Szkoty i zakłady specjalne dla dzieci trudnych w XIX i na poczatku XX wieku, w: Dzieje szkolnictwa i pedagogiki specjalnej, red. S. Mauersberg, Warszawa 1990

Dunin-Sulgustowska M., O slöjdzie i jego stanowisku wobec wychowania $i$ hygieny, „Zdrowie” 1905, nr 1, s. 80.

Ewangelicko-augsburskie Stowarzyszenie opieki nad dziewicami w Warszawie, „Zwiastun Ewangeliczny" 1899, nr 6, s. 175-176.

Fijałek J., Instytucje pomocy materialno-zdrowotnej w Łodzi i okręgu łódzkim, Łódź 1962.

g. [Korczak J.], Od szyi pót metra, „Głos” 1904, nr 20, s. 306.

g. [Korczak J.], Ogrody i skwery, „Głos” 1904, nr 26, s. 402.

g. [Korczak J.], Skwery, „Głos” 1904, nr 23, s. 356.

G. [Korczak J.], Tandeta dobroczynna, „Głos” 1904, nr 11, s. 163.

Gałek C., Myśl pedagogiczna Bolestawa Prusa na tle pozytywizmu polskiego, Zamość 2005.

„Gazeta Radomska” 1890, nr 25, s. 2.

Grot-Bęczkowska W., Söjd, jako czynnik wychowawczy, „Bluszcz” 1902, nr 9, s. 97-98.

Heywood C., Childhood and Children, w: Europe 1789 to 1914: Encyclopedia of the Age of Industry and Empire, red. J. Merriman, J. Winter, t. 1, Thomson Gale, Detroit 2006.

Jachowicz E., Ochrony i zakłady sierot warszawskiego Towarzystwa dobroczynności, w: Niedole dziecięce, Warszawa 1882.

Jastrzębiec A., Przytułek wychowawczo-poprawczy dla dziewcząt, „Tygodnik Mód i Powieści” 1891, nr 13, s. 102.

Jaśkiewicz A., W walce o godność człowieczq..., „Nowe Tory” 1910, nr 1, s. 7.

Jaworski W., Przemiany legalnego życia spolecznego w Królestwie Polskim w latach 1864-1914, Sosnowiec 2006.

Kalendarz Informacyjno-Encyklopedyczny na rok 1914, Warszawa 1914.

Kamiński J.M., O prostytucji, Warszawa 1875.

Kępski C., Towarzystwa dobroczynności w Królestwie Polskim (1815-1914), Lublin 1993.

Kongres Komitetów Walki z handlem kobietami i dziećmi, Warszawa 1930. 
Korczak J., Dzieci ulicy, Warszawa 1901.

Kozłowski W., O rozpowszechnianiu kolonii letnich i ogrodów dziecięcych, „Zdrowie” 1905, nr 2, s. $171-179$.

Kozłowski W.R., Postęy wychowania fizycznego w ostatniem dziesięcioleciu, „Zdrowie” 1908, nr 10-11, s. 172.

Kronika miesięczna, „Biblioteka Warszawska” 1898, nr 4, s. 371-378.

Kronika. Wiadomości społeczne „Prawda” 1904, nr 33, s. 395.

Krzywicki L., Jeden z pogromców, w: idem, Dzieła, t. IX, red. H. Hołda-Róziewicz, Warszawa 1974.

L. L., Pozbawienie rodziców władzy rodzicielskiej, „Gazeta Sądowa Warszawska” 1890, nr 15, s. $237-238$.

Letnie kolonie dla dzieci, „Kłosy” 1882, nr 888, s. 12-13; nr 889, s. 29-30.

M. A., Ograniczenie władzy rodzicielskiej. Skutki wyroków karnych zagranicznych, „Gazeta Sądowa Warszawska" 1896, nr 13, s. 205-206.

M. J. (Marchlewski J.), Korzystna filantropia, „Głos” 1901, nr 26, s. 391.

Margulies B., Prostytucya w Lodzi, „Zdrowie” 1906, nr 8, s. 539-547.

Markiewiczowa H., Działalność opiekuńczo-wychowawcza Warszawskiego Towarzystwa Dobroczynności 1814-1914, Warszawa 2002.

Mazur E., Dobroczynność w Warszawie XIX wieku, Warszawa 1999.

Mogilnicki A., Dziecko i przestepstwo, Warszawa 1916.

Moldenhawer A., Domy moralnie zaniedbanych dzieci, „Zdrowie” 1896, nr 5-7, s. 290-312.

Moldenhawer A., Krótka wiadomość o pierwszych osadach rolnych i o ich założycielach, „Kłosy” 1874 , nr 479-480, s. $158-159$.

Moldenhawer A., O zakładach karnych dla nieletnich przestępców i dzieci potrzebujacych opieki, „Przegląd Sądowy” 1871, t. 10, s. 159-203.

Moldenhawer A., Stowarzyszenia i instytucye zagraniczne opiekujące się dziećmi, w: Niedole dziecięce, Warszawa 1882.

Moldenhawer A., Towarzystwo osad rolnych i przytułków rzemieślniczych oraz jego zakłady, w: Niedole dziecięce, Warszawa 1882.

Moszczeńska I., Dzieci w Warszawie, „Przegląd Pedagogiczny” 1898, nr 20, s. 359.

Nad otchłania, „Gazeta Sądowa Warszawska” 1902, nr 13, s. 196-198.

Nieletni przestępcy, „Gazeta Sądowa Warszawska” 1877, nr 14, s. 111.

Ogrody dla dzieci, „Przegląd Pedagogiczny” 1893, nr 11, s. 145-146.

Orzeszkowa E., O niedolach dziecięcych, „Tygodnik Ilustrowany” 1876, nr 15, s. 236.

Osada rolniczo-karna w Mettray, „Biblioteka Warszawska” 1843, $\mathrm{nr}$ 4, s. 772-778.

Pietkiewicz Z., Opieka społeczna. Dzieci, „Prawda” 1900, nr 47, s. 559.

Połkotycki W., Domy sierot, „Zdrowie” 1896, nr 5-7.

Poseł Prawdy [Świętochowski A.], Liberum veto, „Prawda” 1881, nr 47, s. 562.

Prus B., Dzieci warszawskie, „Tygodnik Ilustrowany” 1905, nr 14, s. 244.

Prus B., Kroniki, oprac. Z. Szweykowski, t. I-XX, Warszawa 1953-1970.

Raś D., Rodziny ubogie i przestępczość od XVI do XX wieku. Warunki życia, badania psychologiczno-społeczne, dobroczynność i wychowanie młodzieży, Kraków 2011.

Sikorska-Kowalska M., Wiatr E., Eódzkie Żydowskie Towarzystwo Ochrony Kobiet w Łodzi 1914-1939, „Studia z Historii Społeczno-Gospodarczej XIX i XX w.” 2008, nr 5, s. 328 i n.

Silva Rerum, „Kronika Rodzinna” 1889, nr 2, s. 63.

Silva Rerum, „Kronika Rodzinna” 1896, nr 6, s. 188.

Sobczyńska M., Kolonie letnie w Ciechocinku dla chorych dzieci z guberni płockiej, „Notatki Płockie" 2007, nr 2, s. 6-10.

Studzieniec, „Gazeta Sądowa Warszawska” 1882, nr 22, s. 175-178. 
Supady J., Powstanie i rozwój kolonii letnich dla dzieci w Łodzi na przełomie XIX i XX wieku, „Zdrowie Publiczne” 1977, nr 3, s. 193-198.

Szycówna A., Ogrody dziecięce imienia Rau'a, „Zdrowie” 1904, nr 1, s. 3-11.

Szycówna A., Ogród zabaw, gier i zajęć praktycznych dla dzieci, „Zdrowie” 1912, nr 8, s. 624-626.

Szymańska H., Z problemów przestępczości nieletnich $w$ drugiej połowie XIX wieku, „Przegląd Penitencjarny" 1964, nr 2, s. 140.

Tchórznicki J., Ogrody do zabaw i gier dla dzieci, „Przegląd Pedagogiczny” 1903, nr 22, s. 267.

Towarzystwo Ochrony Kobiet, „Tygodnik Mód i Powieści” 1902, nr 51, s. 605-606.

Trzeci Zjazd przedstawicieli zakładów poprawczych w Moskwie, „Gazeta Sądowa Warszawska” 1890, nr 36-37, s. 589-590.

„Tygodnik Ilustrowany” 1900, nr 49, s. 974.

„Tygodnik Mód i Powieści” 1887, nr 3, s. 22.

VIII Międzynarodowy Kongres Komitetów Walki z handlem kobietami i dziećmi, Warszawa 1930.

W obronie dzieci, „Głos” 1904, nr 17, s. 262

Warszawski Dom Schronienia św. Matgorzaty, „Czystość” 1905, nr 6, s. 1.

Warszawskie chrześcijańskie Towarzystwo ochrony kobiet, „Czystość” 1909, nr 33-34, s. 524-525.

Wicherkiewicz, Poznańskie kolonie wakacyjne, „Zdrowie” 1886, nr 3, s. 2-3.

Z tygodnia na tydzień, „Tygodnik Ilustrowany” 1899, nr 27, s. 519.

Z życia stowarzyszeń. Opieka nad dziećmi, „Głos” 1897, nr 3, s. 62.

Zbyszewska Z., Ministerstwo polskiej biedy. Z dziejów Towarzystwa Opieki nad Więźniami „Patronat" w Warszawie 1909-1944, Warszawa 1983. 